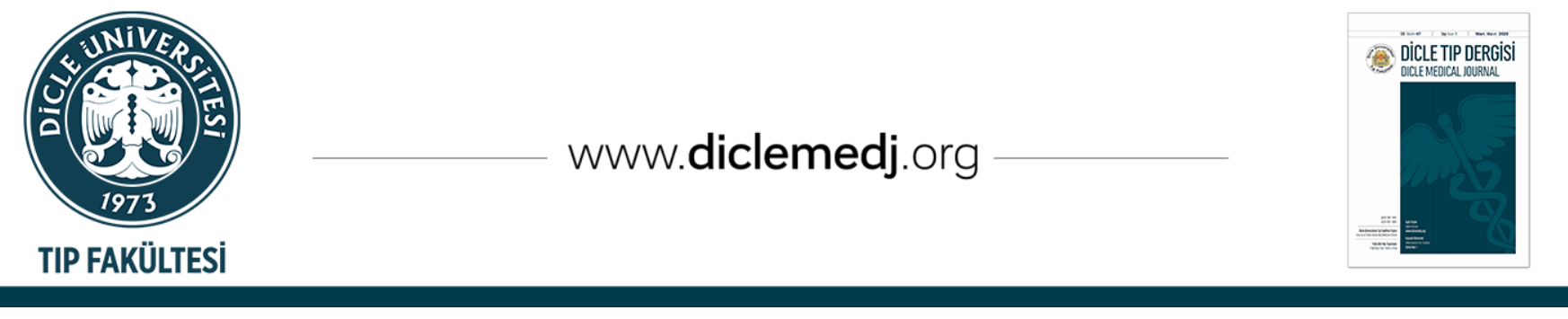

Original Article / Özgün Araştırma

\title{
Pulmonary Artery Pulsatility Index As A Predictor Of Cardiac Mortality In Advanced Chronic Heart Failure: Is It Beyond Right Atrial Pressure?
}

\author{
Ali Doğan iD 1 \\ 1 Istanbul Yeni Yuzyil University, Faculty of Medicine, Gaziosmanpasa Hospital Department of Cardiology İstanbul, Turkey
}

Received: 31.03.2020; Revised: 03.06.2020; Accepted: 16.06.2020

\begin{abstract}
Objective: The effect of pulmonary artery pulsatility index (PAPi) on mortality in patients with advanced chronic heart failure (HF).

Methods: The study included 53 patients with advanced chronic HF, with ejection fraction below 30\%, who underwent right and left catheterization. Two groups were formed according to the development of cardiac mortality.

Results: Of 53 patients in the study group, 18 patients developed cardiac mortality (33.9\%). While male gender and peripheral artery disease were more in the cardiac mortality group, CRP level was also seen more in this group. As stroke volume, aortic pressures, left ventricular systolic pressure were lower in the cardiac mortality group, right atrium pressure (RAP) was higher. PAPi was associated with cardiac mortality and lower in this group $(\mathrm{P}=0.001)$. According to univariate analysis, PAPi and RAP were among predictors of cardiac mortality. However, multivariate analysis indicated that only RAP was an independent predictor. PAPi threshold value for cardiac mortality was calculated as $2.9(88.9 \%$ sensitivity and $74.3 \%$ specificity).
\end{abstract}

Conclusion: PAPi is related with cardiac mortality in advanced HF. However, it is not an independent predictor. PAPi is mostly dependent on right atrial pressure.

Keywords: advanced heart failure, cardiac mortality, pulmonary artery pulsatility index

DOI: 10.5798/dicletip.755709

Correspondence / Yazışma Adresi: Ali Doğan, Istanbul Yeni Yuzyil University, Faculty of Medicine, Gaziosmanpasa Hospital Cardiology Department Gaziosmanpasa, Istanbul, Turkeye-mail: drdali@hotmail.com 


\section{İleri Kronik Kalp Yetmezliğinde Kardiyak Mortalitenin Ön Gördürücüsü Olarak Pulmoner Arter Pulsatilite İndeksi: Sağ Atrial Basıncın Ötesinde mi?}

\section{$\ddot{0} \mathbf{z}$}

Amaç: İleri kronik kalp yetmezliği (KY) hastalarında pulmoner arter pulsatilite indeksinin (PAPi) mortalite üzerine etkisi

Yöntemler: Çalışmaya ileri evre kronik KY olan ejeksiyon fraksiyonu \%30’un altında, sağ ve sol kateterizasyon ișlemi yapılmıș 53 hasta alındı. Kardiyak mortalite gelişimine göre iki grup oluşturuldu.

Bulgular: Çalıșma grubunda bulunan 53 hastadan, 18 hastada kardiyak mortalite geliști (\%33,9). Erkek cinsiyet ve periferik arter hastalığı kardiyak mortalite grubunda daha çok iken, CRP düzeyi de yine bu grupta daha fazla görüldü. Atım hacmi, aortik basınçlar, sol ventrikül sistolik basıncı kardiyak mortalite grubunda daha düşük iken, sağ atrium basıncı (SAB) daha yüksek saptandı. PAPi, kardiyak mortalite ile ilişkili olup, bu grupta daha düşük izlendi (p:0.001). Tek değişkenli analize göre, PAPi ve SAB kardiyak mortalitenin ön gördürücüleri arasındaydı. Ancak, çok değişkenli analiz sadece SAB'nin bağımsız bir ön gördürücü olduğunu göstermiştir. Kardiyak mortalite için PAPi eşik değeri 2.9 olarak hesaplandı (\%88,9 duyarlılık ve \%74,3 özgüllük ).

Sonuç: PAPi, ileri KY'de kardiyak mortalite ile ilişkilidir. Ancak, bağımsız bir ön gördürücü değildir. PAPi çoğunlukla sağ atrial basınca bağımlıdır.

Anahtar kelimeler: ileri kalp yetmezliği, kardiyak mortalite, pulmoner arter pulsatilite indeksi.

\section{INTRODUCTION}

Advanced chronic heart failure (HF) is the progressive deterioration of heart failure symptoms with reduced ejection fraction and biochemical, clinical signs of cardiac failure ${ }^{1,2}$. Involvement of right ventricle (RV) is a serious and independent predictor of cardiac mortality in this group 3,4 . Right heart catheterization (RHC) is an essential diagnostic test for the evaluation of heart transplantation and left ventricular assist device (LVAD) candidates ${ }^{5}$. Several hemodynamic indices have emerged to demonstrate right heart function. As a relatively new marker, pulmonary artery pulsatility index (PAPi) is used to predict RV dysfunction. It is described as the ratio of pulmonary pulse pressure (pulmonary artery systolic minus diastolic pressure) to right atrial pressure (RAP). PAPi was initially described in patients with RV infarction ${ }^{6}$. The development of PAPi is actually based on the need of a parameter independent of cardiac output, which is essential for other parameters of RV function ${ }^{7}$.

Right HF is a significant reason of mortality in LVAD implanted patients ${ }^{8,9}$. PAPi was found to have prognostic role in LVAD implanted patients, as well as patients with advanced HF patients, pulmonary arterial hypertension ${ }^{10,11}$. It was aimed to evaluate the impact of PAPi on the mortality of end stage chronic $\mathrm{HF}$ in this study.

\section{METHODS}

\section{Study population}

The study enrolled patients advanced stage chronic HF patients with left ventricle ejection fraction (LV-EF) $<30 \%$, who underwent right and left heart catheterization in a single center hospital between January 2017 and December 2019. The study group consisted of mostly ambulatory outpatients assessed for heart transplantation or LVAD. However, hospitalized decompensated HF patients were also included to a lesser extent. Functional status of patients were class III and IV. Of 96 consecutively included patients, 43 patients who underwent LVAD implantation or heart transplantation operation were excluded from study. 53 patients were enrolled, cardiac mortality was investigated in this group. The period from right and left heart catheterization time to either cardiac mortality or for living patients, the study ending time (February 2020) was defined 
as the duration of follow-up. Informed consent from all patients were obtained and approval of institutional review board for the study was acquired.

Baseline clinical features, biochemical analyses including complete blood count, mean platelet volume (MPV), red cell distribution width (RCDW), C-reactive protein (CRP), serum urea, creatinine, alanin aminotransferase (ALT), sodium, potassium, low-density lipoprotein cholesterol (LDL-C), high density lipoprotein cholesterol (HDL-C), triglyceride (TG) were assessed. LV-EF and tricuspid annular plane systolic excursion (TAPSE) were also noted according to transthoracic echocardiogram.

Medications patients including angiotensin receptor neprilysin inhibitor (ARNI), angiotensin converting enzyme inhibitors (ACEI), angiotensin II receptor blockers (ARB), beta blockers, mineralocorticoid receptor antagonists (MRA), ivabradine, diuretics and intravenous inotropic agents were also noted.

\section{Cardiac Catheterization}

Right and left cardiac catheterizations were performed to assess hemodynamic status of each patient. Femoral vein and artery were cannulated and the procedure was conducted in supine position of the patients. Cardiac output, cardiac index, stroke volume, stroke volume index, pulmonary vascular resistance (PVR), right atrial pressure (RAP), RV systolic pressure (RV-SP), RV- end diastolic pressure (RV-EDP), pulmonary artery systolic pressure (PA-SP), pulmonary artery diastolic pressure (PA-DP), mean pulmonary artery pressure, aortic systolic pressure, aortic diastolic pressure, mean aortic pressure, left ventricular end diastolic pressure (LV-EDP), left ventricular systolic pressure (LVSP), pulmonary capillary wedge pressure (PCWP) were recorded.

PAPi was calculated as pulmonary pulse pressure divided by the right atrial pressure: PAPi $=($ PASP - PADP $) /$ RAP .

\section{Statistical Analysis}

Statistical analyses were conducted by SPSS software (version 22.0; SPSS Inc., Chicago, IL, USA). Continuous variables were reported as mean \pm standard deviation (SD) or median (2575 percentiles). Kolmogorov-Smirnov test was performed to detect normality of distribution. Independent $t$ test or Mann-Whitney $U$ test was applied according to this result. Frequencies and percentages were defined for categorical data. Comparisons of categorical variables were implemented by Pearson chi square or Fisher's exact test.

Univariate and multivariate analysis were performed to determine the predictors of mortality. Results were expressed with odds ratios (OR) and 95\% confidence intervals (CI).

Receiver operating characteristic (ROC) curve was generated for discriminative ability of PAPi to predict mortality in advanced chronic HF patients. Results were presented as the area under the resulting curve (AUC) and 95\% confidence intervals (CI). A cut-off level of PAPi was determined with sensitivity and specificity. A p value less than 0.05 was accepted to indicate statistical significance.

\section{RESULTS}

53 patients with advanced chronic HF patients were included. Median follow-up duration was 13 months (9-21 months). Of 53 patients, 18 patients (33.9\%) developed cardiac mortality. Two groups were formed in terms of the presence of cardiac mortality. There was no difference between groups $(50.3 \pm 12.9$ vs $51.3 \pm 12.9$, p: 0.793 ) according to age. However, male gender was higher in cardiac mortality group $(77.1 \%$ vs $100 \%$, p: 0.040). Baseline features of the patients were also compared between groups. There was no statistical difference in clinical features including hypertension, diabetes mellitus, hyperlipidemia, chronic renal failure, HF type 
(ischemic or non-ischemic). Contrarily, peripheral artery disease (PAD) was higher in mortality group (5.7\% vs $27.8 \%$, p: 0.025 ).

From biochemical and echocardiographic features, CRP was statistically higher in cardiac mortality group (p:0.007). Other parameters including white blood cell (WBC), hemoglobin, platelet, MPV, RCDW, urea, creatinine, ALT, sodium, potassium, LDL-C, HDL-C, triglyceride , LV-EF, TAPSE were not different between groups.

Therapies including ARNI, ACEI/ARB, beta blockers, MRA, ivabradine, diuretics and inotropic support do not differ in terms of the occurrence of cardiac mortality.

Clinical, biochemical, echocardiographic parameters and medications were showed in Table 1.

Right and left catheterization findings of advanced HF patients were main topics of the study. Even though, heart rate in cardiac mortality group seemed to be higher, it did not reach statistical significance. In cardiac mortality group, stroke volume was lower (p:0.042). Aortic systolic, diastolic, mean pressures and left ventricle systolic pressure were also lower in this group $(\mathrm{p}<0.001$, for all of them). While right atrial pressure [8(7-11) vs 14(11.5-17.7) p: <0.001)] was higher, PAPi was lower in cardiac mortality group [3.1(2.8-3.3)) vs 2.1(2-2.4), p: 0.001)]. Comparison of the catheterization features of the patients were indicated in Table 2.
Table I: Comparison of cardiac mortality $(-)$ and $(+)$ groups in terms of clinical, biochemical, echocardiographic parameters and medications

\begin{tabular}{|c|c|c|c|}
\hline & $\begin{array}{l}\text { Cardiac Mortality } \\
(-) \\
\text { N:35 }\end{array}$ & $\begin{array}{l}\text { Cardiac Mortality } \\
(+) \\
\mathrm{N}: 18\end{array}$ & P value \\
\hline Age, (years) & $50.3 \pm 12.9$ & $51.3 \pm 12.9$ & 0.793 \\
\hline Gender (male), n, \% & $27(77.1)$ & $18(100)$ & 0.040 \\
\hline Hypertension, n, \% & $20(57.1)$ & $12(66.7)$ & 0.502 \\
\hline Diabetes Mellitus, n, \% & $12(34.3)$ & $4(22.2)$ & 0.365 \\
\hline Hyperlipidemia, n, \% & $17(48.6)$ & $8(47.1)$ & 0.918 \\
\hline PAD, n, \% & $2(5.7)$ & $5(27.8)$ & 0.025 \\
\hline $\begin{array}{l}\text { Chronic Renal Failure, } \\
\mathrm{n}, \%\end{array}$ & $12(34.3 \%)$ & $5(27.8)$ & 0.631 \\
\hline $\begin{array}{l}\text { Cardiomyopathy } \\
\text { (ischemic), n, \% }\end{array}$ & $16(45.7)$ & $11(61.1)$ & 0.440 \\
\hline WBC, $\mu \mathrm{l}$ & $9.1 \pm 2.8$ & $8.0 \pm 2.0$ & 0.115 \\
\hline Hemoglobin, g/dL & $13.7(12.8-14.9)$ & $12.1(9.8-14.6)$ & 0.138 \\
\hline Platelet, $10^{3} / \mu \mathrm{l}$ & $222.8 \pm 83.5$ & $257 \pm 107.3$ & 0.204 \\
\hline MPV, fL & $10.8 \pm 0.8$ & $10.7 \pm 0.8$ & 0.865 \\
\hline RCDW, \% & $41(38.5-44.9)$ & $48.2(41.5-51.7)$ & 0.138 \\
\hline CRP, mg/dL & $4.4(2.3-13)$ & $18(7.4-35.7)$ & 0.007 \\
\hline Urea, $\mathrm{mg} / \mathrm{dL}$ & $20(15.8-32.8)$ & $22(16.7-28.2)$ & 0.985 \\
\hline Creatinine, $\mathrm{mg} / \mathrm{dL}$ & $1.1(0.9-1.3)$ & $0.9(0.7-1.4)$ & 0.145 \\
\hline ALT, $U / L$ & $25.5(19.5-38.5)$ & $24.0(17.7-74.2)$ & 0.597 \\
\hline Sodium, mEq/L & $140(137-141)$ & $137.5(135.7-142.29$ & 0.346 \\
\hline Potassium, mEq/L & $4.1(3.9-4.7)$ & $4.5(3.9-4.7)$ & 0.833 \\
\hline LDL-C, mg/dL & $102.7 \pm 29.9$ & $97 \pm 49.1$ & 0.605 \\
\hline HDL-C, mg/dL & $37.1 \pm 9.3$ & $37.1 \pm 13.7$ & 0.995 \\
\hline Triglyceride, mg/dL & $137(110-170)$ & 104(74-151) & 0.110 \\
\hline LV-EF, \% & $22.6 \pm 3.6$ & $22.0 \pm 3.7$ & 0.595 \\
\hline TAPSE, mm & $17(14.8-19)$ & $15.6(14-17)$ & 0.130 \\
\hline \multicolumn{4}{|l|}{ Medications } \\
\hline ARNI, n, \% & $8(22.9)$ & $2(11.1)$ & 0.301 \\
\hline ACEI/ARB, n, \% & $23(65.7)$ & $13(72.2)$ & 0.631 \\
\hline Beta Blockers, n, \% & 33 (94.3) & $14(77.8)$ & 0.072 \\
\hline MRA, n, \% & 29 (82.9) & $17(94.4)$ & 0.238 \\
\hline Diuretics, n, \% & 29(82.9) & $18(100)$ & 0.062 \\
\hline Ivabradine, $\mathrm{n}, \%$ & $9(25.7)$ & $5(27.8)$ & 0.872 \\
\hline Inotropic support n, \% & $5(14.3)$ & $6(33.3)$ & 0.105 \\
\hline
\end{tabular}


Table II: Comparison of right and left catheterization parameters in cardiac mortality $(-)$ and $(+)$ groups

\begin{tabular}{|c|c|c|c|}
\hline & $\begin{array}{l}\text { Cardiac Mortality } \\
(-)\end{array}$ & \begin{tabular}{|l|} 
Cardiac \\
Mortality (+)
\end{tabular} & $P$ value \\
\hline \begin{tabular}{|l|} 
Cardiac output, \\
L/min
\end{tabular} & $3.8 \pm 0.9$ & $3.4 \pm 0.6$ & 0.095 \\
\hline \begin{tabular}{|l|} 
Cardiac index, \\
$\mathrm{L} / \mathrm{min} / \mathrm{m}^{2}$
\end{tabular} & $1.9(1.7-2.2)$ & $1.7(1.5-2.0)$ & 0.185 \\
\hline 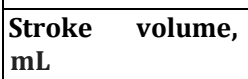 & $48.6 \pm 13.1$ & $41.1 \pm 10.8$ & 0.042 \\
\hline $\begin{array}{l}\text { Stroke volume } \\
\text { index, } \mathrm{mL} / \mathrm{m} 2\end{array}$ & $25.4 \pm 7.1$ & $21.6 \pm 5.6$ & 0.055 \\
\hline $\begin{array}{l}\text { Heart rate (per } \\
\text { minute) }\end{array}$ & $82.2 \pm 15.6$ & $86.9 \pm 15.9$ & 0.311 \\
\hline Aorta DP, mmHg & $135.3 \pm 27.9$ & $110 \pm 12.3$ & $<0.001$ \\
\hline \begin{tabular}{|l} 
Aorta SP, $\mathbf{m m H g}$ \\
\end{tabular} & $81.4 \pm 15.2$ & $64.0 \pm 8.2$ & $<0.001$ \\
\hline Aorta MP, mmHg & $100.0 \pm 19.4$ & $80.3 \pm 9.4$ & $<0.001$ \\
\hline LV-EDP, mmHg & $20(18-30)$ & $22(16.5-27.2)$ & 0.760 \\
\hline LV-SP, mmHg & $141.0 \pm 30.5$ & $114.6 \pm 16.4$ & $<0.001$ \\
\hline \begin{tabular}{|l} 
RV-EDP, mmHg \\
\end{tabular} & $10(8-13)$ & $9.5(8-14)$ & 0.777 \\
\hline RV-SP, mmHg & $57.3 \pm 17.1$ & $61.5 \pm 16.1$ & 0.391 \\
\hline PA-SP, mmHg & $51.7 \pm 17.1$ & $60.6 \pm 16.5$ & 0.076 \\
\hline PA-DP, mmHg & $23.8 \pm 6.9$ & $26.4 \pm 5.5$ & 0.174 \\
\hline PA-MP, mmHg & $34.4 \pm 11.2$ & $39.3 \pm 8.7$ & 0.111 \\
\hline RAP, mmHg & $8(7-11)$ & $14(11.5-17.7)$ & $<0.001$ \\
\hline \begin{tabular}{|l} 
PCWP, $\mathbf{m m H g}$ \\
\end{tabular} & $22(18-30)$ & $26(19-22.5)$ & 0.397 \\
\hline PVR, Wood Units & $3(2-4)$ & $3.5(2.7-5)$ & 0.118 \\
\hline PAPi & $3.1(2.8-3.3)$ & $2.1(2-2.4)$ & 0.001 \\
\hline
\end{tabular}

DP: Diastolic pressure, SP: Systolic pressure, MP: Mean pressure, EDP: Enddiastolic pressure, PA: Pulmonary artery

Univariate analysis indicated that PAD, CRP, stroke volume, aortic systolic, diastolic, mean pressures, left ventricle systolic pressure, RAP and PAPi were significantly associated with cardiac mortality. A multivariate analysis was conducted to define the independent predictors. RAP (p: 0.036, OR:1.706, 95\% CI (1.037-2.806) was found to be an independent predictor of cardiac mortality. Univariate and multivariate logistic regression analysis were showed in Table 3.
Table III: Univariate and multivariate analysis showing predictors of cardiac mortality

\begin{tabular}{|l|c|c|c|c|c|c|}
\hline \multirow{2}{*}{} & \multicolumn{3}{|c|}{ Univariate analysis } & \multicolumn{3}{c|}{ Multivariate analysis } \\
\cline { 2 - 7 } & $\begin{array}{c}\text { Odds } \\
\text { ratio }\end{array}$ & $\begin{array}{c}\text { 95\% C.I. } \\
\text { (Lower- } \\
\text { Upper) }\end{array}$ & P & $\begin{array}{c}\text { Odds } \\
\text { ratio }\end{array}$ & $\begin{array}{c}\text { 95\% C.I. } \\
\text { (Lower- } \\
\text { Upper) }\end{array}$ & p \\
\hline PAD & 6.346 & $\begin{array}{c}1.091- \\
36.921\end{array}$ & $\begin{array}{c}0.04 \\
0\end{array}$ & & & \\
\hline CRP & 1.044 & $1.005-1.083$ & $\begin{array}{c}0.02 \\
5\end{array}$ & & & \\
\hline Stroke \\
volume & 0.951 & $0.904-0.999$ & $\begin{array}{c}0.04 \\
7\end{array}$ & & & \\
\hline Aorta SP & 0.948 & $0.914-0.982$ & $\begin{array}{c}0.00 \\
3\end{array}$ & & & \\
\hline Aorta DP & 0.892 & $0.833-0.955$ & $\begin{array}{c}0.00 \\
1\end{array}$ & & & \\
\hline $\begin{array}{l}\text { Aorta } \\
\text { Mean }\end{array}$ & 0.913 & $0.862-0.966$ & $\begin{array}{c}0.00 \\
2\end{array}$ & & & \\
\hline LV SP & 0.955 & $0.925-0.986$ & $\begin{array}{c}0.00 \\
5\end{array}$ & & & \\
\hline RAP & 1.587 & $1.226-2.055$ & $\begin{array}{c}<0.0 \\
01\end{array}$ & 1.706 & $\begin{array}{c}1.037- \\
2.806\end{array}$ & 0.03 \\
\hline PAPi & 0.251 & $0.096-0.654$ & $\begin{array}{c}0.00 \\
5\end{array}$ & & & \\
\hline ROC & & & & & & \\
\hline
\end{tabular}

ROC curve was also generated for prediction of cardiac mortality. The cut-off value of PAPi for cardiac mortality was determined as 2.9 as a result of ROC curve analysis [(88.9\% sensitivity and 74.3\% specificity, AUC: 0.787, p:0.001, 95\% CI (0.646-0.928)]. ROC analysis was depicted in Figure 1.

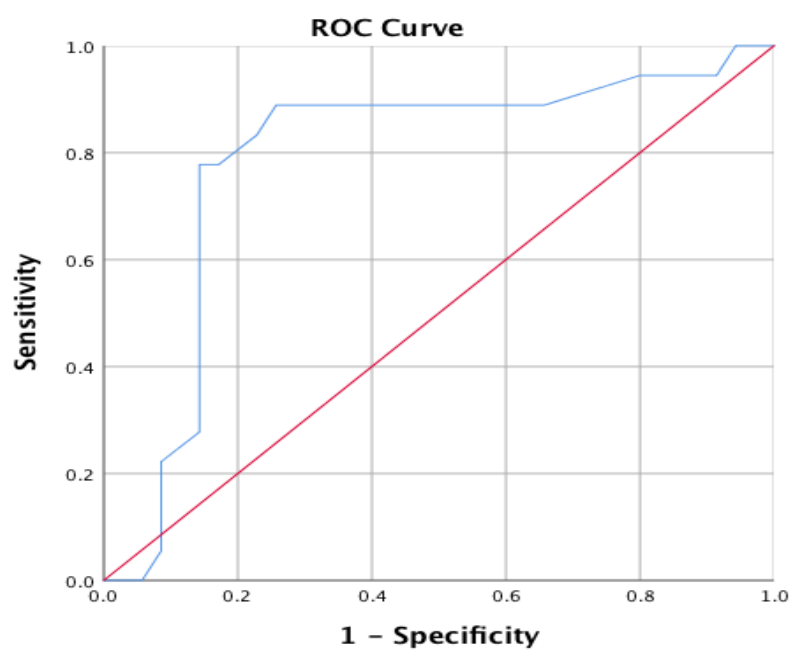

Figure 1: ROC analysis of PAPi and cardiac mortality 308 


\section{DISCUSSION}

This study indicates that PAPi is associated with cardiac mortality in advanced chronic HF patients. RAP, however not PAPi is an independent predictor of cardiac mortality.

Evaluation of RV function is a major determinant of assessment of right HF. However, it could be difficult with transthoracic echocardiography due to retrosternal placement of RV 7. Predictive value of echocardiography is not sufficient particularly after LVAD implantation and cardiac surgery ${ }^{12-}$ 14. This condition necessitates the use of a novel parameter in right HF. PAPi has arisen as a relatively new invasively detected marker indicating RV contractile function. It also shows that RAP in the denominator of the fraction is an identifier of RV failure. Since its first application in RV myocardial infarction, different patient groups were investigated. Apart from preoperative evaluation of LVAD planned patients, it was also examined intraoperatively during LVAD implantation ${ }^{15}$.

Kochav et al examined advanced chronic HF patients and indicated that PAPi was a predictor of mortality and hospitalization at 6 months ${ }^{10}$. This study also showed that it was associated with cardiac mortality. While PAPi was not an independent predictor for cardiac mortality, RAP was an independent predictor in our study. Stroke volume and aortic pressures were also associated with cardiac mortality in this study. Kochav et al study had 190 patients with RHC and a median PAPi value of 2.35. Median value of PAPi in cardiac mortality group was 2.1, whereas median value of PAPi in patient without cardiac mortality was 3.1 in this study. Besides, in terms of ROC analysis, a cut-off PAPi value of 3.65 was found by Kochav et al. Another study investigating the effect of PAPi in advanced stage HF patients by Cesini et al concluded that PAPi lower than 1.41 was related to the adverse clinical results. Median PAPi was 2.2 in the latter study ${ }^{16}$. In contrast, the current study indicated a cut-off value of 2.9 with $88.9 \%$ sensitivity and $74.3 \%$ specificity for cardiac mortality. In contradiction to these studies, Lala et al proposed that PAPi was not an indicator of mortality in patients with cardiogenic shock due to acute myocardial infarction ${ }^{17}$.

The changes in PAPi values are largely dependent RAP rather than pulmonary arterial pulse pressure ${ }^{16}$. The current study was compatible with this finding, RAP seemed to be major determinant in PAPi calculation. The number of the patients involved should be increased to understand whether or not PAPi is beyond RAP.

Cut-off values of PAPi for mortality can vary between study groups. This value could be lowest in RV infarction. It is higher in LVADimplanted patients. The threshold increases in chronic HF patients as in this study. Mazimba et al also found the association of PAPi with survival in pulmonary arterial hypertension patients ${ }^{11}$. Median PAPi was 5.8, even higher than chronic HF population.

Deterioration of right heart following cardiac surgery is related with mortality and morbidity. Rong et al studied this topic and indicated preoperative PAPi was a predictor of postoperative RV dysfunction ${ }^{18}$. Moreover, after heart transplantation, lower PAPi was found to related with acute kidney injury ${ }^{19}$.

CRP level as a sign of inflammation was found to be associated with cardiac mortality in the study. This finding was consistent with previous studies. High CRP level is linked to adverse clinical results in chronic $\mathrm{HF}^{20}$.

\section{LIMITATIONS}

Limitations of the study were as follows. Firstly, it was retrospective, single-center study. Therefore, it was liable to bias. The number of patients enrolled in the study was relatively small. RHC was performed for once, no serial 
examination was conducted. Therefore, changes in PAPi values were not evaluated.

\section{CONCLUSION}

PAPi is associated with cardiac mortality in advanced chronic HF patients. PAPi is not an independent predictor of cardiac mortality. It is largely influenced by right atrial pressure. Studies involving a higher number of patients are needed to determine the effect of right atrial pressure on PAPi.

Ethics Committee Approval: This study was compliant with the Declaration of Helsinki and approved by Istanbul Yeni Yuzyil University Clinical Research Ethics Committee (16.01.2020/001).

Declaration of Conflicting Interests: The authors declare that they have no conflict of interest.

Financial Disclosure: No financial support was received.

\section{REFERENCES}

1. Kalmanovich E, Audurier Y, Akodad M, et al. Management of advanced heart failure: a review. Expert Rev Cardiovasc Ther. 2018; 16: 775-94

2. Metra M, Ponikowski P, Dickstein $\mathrm{K}$, et al. Advanced chronic heart failure: A position statement from the Study Group on Advanced Heart Failure of the Heart Failure Association of the European Society of Cardiology. Eur J Heart Fail. 2007; 9: 684-94.

3. Merlo M, Gobbo M, Stolfo D, et al The Prognostic Impact of the Evolution of RV Function in Idiopathic DCM. Jacc-Cardiovasc Imag. 2016; 9: 1034-42.

4. Akıl MA, Ertas F, Kaya H, et al. Comparison of right ventricular functions according to infarct localization using advanced echocardiographic methods in myocardial infarction with ST elevation. Dicle Med J. 2012; 3: 561-6.

5. Feldman D, Pamboukian SV, Teuteberg JJ, et al. The 2013 International Society for Heart and Lung Transplantation Guidelines for mechanical circulatory support: executive summary. J Heart Lung Transplant. 2013; 32: 157-87.

6. Korabathina R, Heffernan KS, Paruchuri V, et al. The pulmonary artery pulsatility index identifies severe right ventricular dysfunction in acute inferior myocardial infarction. Catheter Cardiovasc Interv. 2012; 80: 593-600.

7. Lim HS, Gustafsson F. Pulmonary artery pulsatility index: physiological basis and clinical application. Eur J Heart Fail. 2020; 22: 32-8.

8. Kang G, Ha R, Banerjee D. Pulmonary artery pulsatility index predicts right ventricular failure after left ventricular assist device implantation. J Heart Lung Transplant. 2016; 35: 67-73.

9. Morine KJ, Kiernan MS, Pham DT, Paruchun V, Denofrio D, Kapur NK. Pulmonary artery pulsatility index is associated with right ventricular failure after left ventricular assist device surgery. J Card Fail. 2016; 22: 110-6.

10. Kochav SM, Flores RJ, Truby LK, Topkara VK. Prognostic impact of pulmonary artery pulsatility index (PAPi) in patients with advanced heart failure: insights from the ESCAPE trial. J Card Fail. 2018; 24:453-9.

11. Mazimba S, Welch TS, Mwansa $\mathrm{H}$, et al. Haemodynamically derived pulmonary artery pulsatility index predicts mortality in pulmonary arterial hypertension. Heart Lung Circ. 2019; 28: 752-60.

12. Kukucka M, Stepanenko A, Potapov E, et al. Rightto-left ventricular end-diastolic diameter ratio and prediction of right ventricular failure with continuous-flow left ventricular assist devices. J Heart Lung Transplant. 2011; 30: 64-9.

13. Kato TS, Farr M, Schulze PC, et al Usefulness of two-dimensional echocardiographic parameters of the left side of the heart to predict right ventricular failure after left ventricular assist device implantation. Am J Cardiol. 2012; 109: 246-51.

14. Gronlykke L, Ihlemann N, Ngo AT, et al. Measures of right ventricular function after transcatheter versus surgical aortic valve replacement. Interact Cardiovasc Thorac Surg. 2017; 24: 181-7.

15. Gudejko MD, Gebhardt BR, Zahedi F, et al. Intraoperative hemodynamic and 
echocardiographic measurements associated with severe right ventricular failure after left ventricular assist device implantation. Anesth Analg. 2019; 128: $25-32$.

16. Cesini S, Bhagra S, Pettit SJ. Low Pulmonary Artery Pulsatility Index Is Associated With Adverse Outcomes in Ambulatory Patients With Advanced Heart Failure. J Card Fail. 2020; 26: 352-9.

17. Lala A, Guo Y, Xu JF, et al. Right ventricular dysfunction in acute myocardial infarction complicated by cardiogenic shock: a hemodynamic analysis of the Should We Emergently Revascularize Occluded Coronaries for Cardiogenic Shock (SHOCK) trial and registry. J Card Fail. 2018; 24: 148-56.
18. Rong LQ, Rahouma M, Neuburger PJ, et al. Use of Pulmonary Artery Pulsatility Index in Cardiac Surgery. J Cardiothorac Vasc Anesth. 2019 Sep 27. pii: S1053-0770(19)30984-X. doi: 10.1053/j.jvca.2019.09.023. (Epub ahead of print]

19. Guven G, Brankovic M, Constantinescu AA, et al. Preoperative right heart hemodynamics predict postoperative acute kidney injury after heart transplantation. Intensive Care Med. 2018; 44: 58897.

20. Pellicori P, Zhang J, Cuthbert J, et al. Highsensitivity C-reactive protein in chronic heart failure: patient characteristics, phenotypes, and mode of death. Cardiovasc Res. 2020; 116: 91-100. 